\title{
PAKARNA (Papan Angka Berwarna) in Arithmetic Series Material
}

\author{
Rahayu Kariadinata ${ }^{1}$, Juariah $^{2}$, Anis Niswatul Maula ${ }^{3}$ \\ \{rahayu.kariadinata@uinsgd.ac.id ${ }^{1}$, anisniswatul28@gmail.com ${ }^{3}$ \} \\ Mathematics Education Department, UIN Sunan Gunung Djati Bandung, \\ Bandung, Indonesia
}

\begin{abstract}
PAKARNA (Papan Angka Berwarna) is a learning medium used to see the basic concepts of arithmetic sequence material. PAKARNA learning media (Papan Angka Berwarna) is able to provide direct experience to students so that it is easy to understand the concept of arithmetic sequence material, besides that it is easy to use so that learning arithmetic sequences can be more effective and efficient, easy to manufacture, the learning media consists of several colors so as to attract the attention of students in learning mathematics. There are three aspects of accessing media experts, namely the content feasibility components, presentation components and graphic components of PAKARNA which are managed by media experts and mathematics teachers. The results obtained by the proportion of media validation for feasibility in total were $80 \%$, that the PAKARNA media was feasible to be used as a classroom learning medium. Most (69\%) students neglect positivity towards learning mathematics using PAKARNA learning media. This means that students are happy with learning using PAKARNA media.
\end{abstract}

Keywords: PAKARNA, Arithmetic Series, Learning Mathematics

\section{Introduction}

Nowadays, the rapid development of technology and science results in the ability and creativity of teachers in finding learning techniques that can stimulate students' understanding, talents and interests to be better and more diverse [1]. In learning, innovations are continuously carried out, one of which is through media that can be adapted to various existing methods. In the world of education today, there is a new paradigm in which learning makes the teacher as a companion and guide while students become the center of learning. Preliminary studies that have been conducted at SMP Muhammadiyah 10 Bandung show that students' mathematical communication skills are still not good. This was reinforced by the results of the students' mathematical communication skills test in the class with three description questions. The three items contain mathematical communication indicators [2]. These indicators include:

a. Provide answers by modeling concrete and algebraic problems.

b. Reflecting real objects and pictures into mathematical ideas.

c. Express mathematical concepts by expressing everyday events in mathematical language or symbols. 
To maximize learning activities and to improve students 'abilities in understanding the concepts of the material being studied so as to improve students' mathematical communication skills, learning media are used [3]. Media are various components that exist in the scope of learning that can help in the learning process. Learning media is one that can channel or convey messages from a source in a planned manner so that there is a process where the recipient can process it effectively and efficiently in a conducive learning environment.

In general, learning media has uses to clarify the learning material so that when the teacher explains it is not too verbal so that students understand more easily, can overcome the limitations of learning space and time in the school environment because in learning in school students must have predetermined competencies and can increase student learning motivation, make learning more interactive and provide learning experiences using the same learning media for all students [4].

From the opinion about the media, it is also known that the learning media functions as a learning tool as well as a learning aid. Learning media has a meaning that is almost the same as learning resources. Learning media can be used as a learning resource and vice versa learning resources can be used as a learning medium. Learning resources have a wider scope than learning media. Because not all learning sources can become learning media, while learning media is a medium for channeling messages.

One of the other media that can be used to develop mathematics learning media is to use PAKARNA (Papan Angka Berwarna). PAKARNA (Papan Angka Berwarna) is a learning medium used to find out the basic concepts of arithmetic sequence material. There are elements in the PAKARNA (Papan Angka Berwarna), namely a house shape board which is symbolized as a different value for each tribe, a box with flowers to symbolize each positive term, a plain box to represent each negative term, marbles are represented as the writing of the numbers for each term, the picture of a tree is symbolized to write down the value of each tribe and a number to write or represent the different values and terms on the house shape board and the picture of a tree.

PAKARNA learning media (Papan Angka Berwarna) is able to provide direct experience to students so that it is easy to understand the concept of arithmetic sequence material, besides that it is easy to use so that learning arithmetic sequences can be more effective and efficient, easy to manufacture, the learning media consists of several color so that it attracts the attention of students in learning mathematics, as well as cheap, because the learning media PAKARNA (Papan Angka Berwarna) uses wooden boards that are not too expensive, plastic boxes are widely used in the community, marbles are used to play by children, and number papers found in bookstores or grocery stores around the house.

Learning media are used by teachers so that learning can run effectively and efficiently and can help students more easily understand the material being studied. According to Komlasari [5] learning media is expected to provide benefits among other things:

a. Clarify the message so that it is not overly verbalistic.

b. Overcoming the limitations of space, time, energy, and sensory power.

c. Generating passion for learning, more direct interaction between students and learning resources.

d. Enable children to learn independently according to their visual, auditory and kinesthetic talents and abilities.

e. Giving the same stimulation, equalizing experiences and causing the same perception

The author seeks to develop learning media PAKARNA (Papan Angka Berwarna) is a learning medium designed to facilitate students in understanding the concept of arithmetic sequence material. The PAKARNA learning media (Papan Angka Berwarna) is made using a 
board which is designed to have a house shape board which is used to write down the difference in the different values of each tribe, there are boxes with plain pictures and flowers. A box with a plain picture is represented as a negative term (-), a box with a flower is represented as a positive term $(+)$, the box is used as a container for storing marbles where the marbles are represented as numbers. The tree image is used to write down how many tribes are in the flower and plain box. And there are numbers to represent or write different values and terms. The steps for using PAKARNA (Papan Angka Berwarna) are as follows:

a. Preparation before using the expert media

At this stage, the teacher must prepare and ensure various things that can support the use of PAKARNA media so that they can be used when learning takes place. In addition, the teacher must also master the procedures for using the PAKARNA media. The things that must be prepared include:

1) The teacher prepares the equipment and ensures that the PAKARNA media can be used when learning takes place.

2) In the desert, studying the method of using expert because teacher must be able to explain to students the procedures for using PAKARNA.

b. Activities during the day using PAKARNA media

At this stage, it must be able to condition students to remain orderly so that learning can run effectively and so that student concentration and interest in learning are maintained. At this stage the learning activity is to explain the concept of arithmetic sequences and sequences [6]. The steps for using PAKARNA media in this stage are as follows:

The teacher prepares marbles for students.

The teacher asks the students to put a few marbles into the boxes with the pictures of the first, second, third flowers and so on in PAKARNA. For example, students are asked to determine the number of marbles in the 5 boxes provided in PAKARNA. Students are asked to enter 2 marbles in the first box,

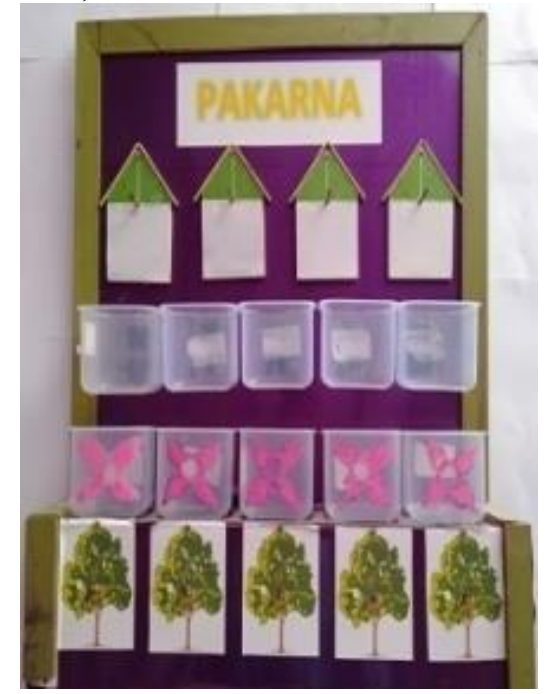

Fig. 1. PAKARNA Board

Make sure each box has a fixed difference from the squares that are close together, which is 2 marbles. Write down how many marbles are in each box with the flower picture into each 
tree in PAKARNA. Because you enter 2 marbles in the first box, write the number 2 in the first tree image. Write down the difference between the marbles in the box with the first flower and the box with the second flower. Since the difference between the marbles in the first box and the second box is 2 marbles, then write the number 2 in the place prepared, namely in the first house image. Repeat the above steps from the next flower box on the tree image provided in the PAKARNA learning media [7].

From the results of the experiment above, it was found that each marble in the box formed a number pattern, namely $2,4,6,8$, and 10 , then the teacher asked the students to add up the number patterns so that they obtained a value of 30 . The teacher explained the basic concept of sequences and the arithmetic sequence, which is 2 marbles entered in the first box called the first term, 4 marbles in the second term, 6 marbles entered in the third third term, 8 marbles entered in the fourth term box, and 10 marbles entered in the fourth term. entered in the fifth box is the fifth term. The difference in marbles from each adjacent box is 2 marbles or it can be called the difference $(b)=2$, to determine the number of marbles in the third term can be obtained by adding the number of differences into the second term such as $\mathrm{U} 2+\mathrm{b}=\mathrm{U} 3$. Mean while, to determine the total number of marbles, it can be determined by adding up the number of marbles in the first term and the number of different marbles from the second term to the desired number of terms or it can be written with the formula $\mathrm{Sn}=\frac{n}{2}[2 \mathrm{a}+(\mathrm{n}-1) \mathrm{b}]$ [8]. Students are asked to observe and explain and re-practice what the teacher is modeling.

c. Follow up activities

This stage is the stage to find out whether the learning objectives have been achieved, and to strengthen understanding of the material that has been conveyed through the PAKARNA media and provide an evaluation of the learning outcomes. The steps are as follows:

The teacher provides practice questions to students regarding the learning material that has been given previously. The teacher repeats the lesson about understanding arithmetic sequences and series if there are still many errors in student learning outcomes using the median expert.

\section{Method}

This research uses the method of research and development (Research and Development). Research and development or Research and Development (R\&D) is a process or steps to develop a new product, or to improve existing products, which can be accounted [9]. Products are meant not only in the form of objects such as books and modules, but can also be software such as computer programs for data management or classroom learning.

In this study, researchers used only 7 steps, namely: potential and problems, data collection, product design, design validation, design revision, product testing, and the final product because the research was conducted on a small scale. This is because in developing PAKARNA media, there are no product revisions, use trials and product revisions. The use trial stage is deemed unnecessary because it has been carried out at the product trial stage along with its revision.

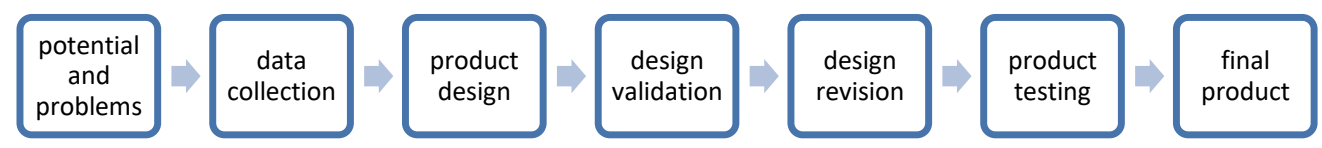

Fig. 2. Steps for Using the modified R\&D method 
Based on Sugiyono's modified Research and Development (R\&D) method [2], the steps to be taken in this study are:

1. Potentials and problems

At the potential and problem stages, researchers conducted observations and interviews to find out the potential and problems. Researchers enter the classroom to observe the mathematics learning process, then interview the mathematics teacher to find out how the learning process is in class and how the attitudes of students in learning mathematics and how the level of students' mathematical communication skills. In addition to interviewing teachers, researchers also interviewed several students to find out how the students 'opinions in learning mathematics and students' expectations in learning mathematics make learning more meaningful and enjoyable. Furthermore, the researcher carried out a preliminary test to find out the students' mathematical communication abilities then from the results of the preliminary study used as the basis for a background in developing learning media.

2. Data collection

In the data collection stage, researchers collect data and information that can be used for product planning. Collecting data in this study is related to the results of observational data such as how the mathematics learning process is carried out, the results of interviews with teachers and students, and the results of the initial tests of students' communication skills and reviewing literature such as journals, SMP / MTs class 7 mathematics books.

\section{Product design}

The next step is designing the PAKARNA media. PAKARNA media is made of plywood boards and made in such a way that there is a board that forms a house with storage boxes with plain pictures and flowers and trees. In addition, marbles or other objects that are used as numeric symbols are also needed in research. As well as numbers to write numbers on a house shape board and a picture of a tree.

\section{Design validation}

Validasi design is an assessment based on rational thinking, before the facts in the field. The next step after the initial product is finished is consultation with a team of experts consisting of media experts and subject teachers.

Media PAKARNA is based on the rules adopted from Kariadinata. There are 3 aspects that are assessed, namely the components of the feasibility of the content, presentation and graphics of the PAKARNA which were then assessed by the experts and mathematics teachers at the Muhammadiyah 10 Bandung Department of Education, where the research was conducted.

\section{Revised design}

After the 3 aspects assessed, namely the content feasibility component, presentation and product design graphics were validated by media experts and field teachers, suggestions and input were obtained. Then the suggestions and inputs are used to improve and produce better and more attractive products. 
6. Testing the product

After the design revision was carried out, the PAKARNA media effectiveness test was carried out in learning. In this trial two classes were used, namely class VIII A and VIII B. The research approach used in this research is a quantitative approach with a quasiexperimental research method and the design used is the Nonequivalent control group design. In this method, the research class is divided into two categories, namely the experimental class and the control class. The experimental class and the control class were given a pretest to find out the initial abilities of students' mathematical communication abilities. Furthermore, in the experimental class, a learning process was carried out using PAKARNA media and a control class whose learning did not use PAKARNA media [10].

After carrying out the learning process, students are then given a final test (posttest) with the same test questions as the pre-test. Giving pretest and posttest is to determine the increase in students' mathematical communication skills after being given treatment.

Table 1. Research Design PAKARNA

\begin{tabular}{|l|c|c|c|}
\hline & Pretes & Treatment & Posttest \\
\hline Experiment (PAKARNA media) & $\mathrm{O}$ & $\mathrm{X}$ & $\mathrm{O}$ \\
\hline Control (Expository) & $\mathrm{O}$ & & $\mathrm{O}$ \\
\hline
\end{tabular}

Information:

$\mathrm{X}$ : Learning using media PAKARNA

$\mathrm{O}$ : The questions tested for the experimental class and the control class

(Ruseffendi, 2005: 53)

To determine the feasibility of using the PAKARNA media, it was obtained from the results of the students' mathematical communication skills test, the results were obtained in the form of pretest and posttest scores. Then the obtained value is analyzed to obtain N-gain and a " $t$ " test is carried out to determine the difference in student achievement in the experimental class and the control class. The scale of students' attitudes about the PAKARNA media after the lesson was carried out

\section{Final products}

The final product of this research is the revised PAKARNA media which has been validated by experts and teachers, tested the feasibility of the product, and then can be used in mathematics learning with arithmetic sequence and series material at SMP Muhammadiyah 10 Bandung.

\subsection{Types and sources of data}

The types of data used in this research are quantitative and qualitative. Quantitative data is test result data in the form of numbers obtained from the pretest and posttest scores. Whereas qualitative data is data generated from observations of student and teacher activities and the scale score of students' attitudes towards the PAKARNA media.

Sampling in this study using probability sampling, namely simple random sampling. Two classes were selected from the entire population used in the study, namely class VIII B as the experimental class and class VIII A as the control class.

\subsection{Instruments}

The instruments used in this research are:

1. Expert validity checklist sheet 
This instrument is used to assess the feasibility of media based on specific aspects of assessment as media validation that has been developed by experts for further use in the mathematics learning process in the classroom in improving mathematical communication skills. This instrument contains a checklist of content feasibility components, presentation components and graphic components for media experts [11].

\subsection{Tes}

The instrument used in this study was a test of mathematical communication skills in the form of descriptive questions and material lines and arithmetic series. The questions were given to students during the pretest and posttest, where the questions given were the same. The questions consist of two packages of questions about the type of A and B each of which has 5 items.

\subsection{Non-test}

The non-test instrument used was an attitude scale questionnaire. The questionnaire contained 3 indicators, namely students' attitudes towards mathematics learning, students' attitudes towards learning using PAKARNA media and students' attitudes towards mathematical communication skills [12].

This study used the Attitude Scale Model Likert with the priori method, namely the attitude scale model questionnaire calculated the score of each item according to the responses of the respondents. Each statement is completed with four answer choices: Strongly Agree (SS), Agree (S), Disagree (TS), and Strongly Disagree (STS).

The instrument that has been made is then analyzed. To analyze the research instrument, it is carried out as follows:

Instrument analysis technique

The instrument is in the form of an expert validity checklist sheet which is analyzed based on the eligibility rules of teaching materials according to BSNP for PAKARNA media which are based on the rules adopted from Kariadinata. The research data were then analyzed using the rating scale measurement scale determined by the following formula:

Description:

$$
\mathrm{p}=\frac{\text { score from data collection }}{\text { ideal score }} .100 \%
$$

$\mathrm{P}=$ percentage of product validity

Skor ideal $=$ highest score per item $\mathrm{x}$ number of respondent of item

The instrument in the form of tests of mathematical communication skills in the analysis includes validity, reliability, differentiation, and difficulty level.

a. Validity

Calculating the validity of the problem, the product-moment correlation formula is used using the following raw score:

$$
r_{x y}=\frac{N \sum X Y-\left(\sum X\right)\left(\sum Y\right)}{\sqrt{\left\{N \sum X^{2}-\left(\sum X\right)^{2}\right\}\left\{N \sum Y^{2}-\left(\sum Y\right)^{2}\right\}}}
$$

Information:

rxy $=$ coefficient of correlation between variable $\mathrm{X}$ and variable $\mathrm{Y}$

$\mathrm{X}=$ Score of each item

$\mathrm{Y}=$ The total score of each student in the test 
$\mathrm{N} \quad=$ Number of female students

$\sum X Y=$ Sum multiplication $\mathrm{XY}$

b. Reliability

Calculating the reliability of the problem, then using the following Alpha formula:

$$
r_{11}=\left(\frac{n}{n-1}\right)\left(1-\frac{\sum S_{i}{ }^{2}}{S_{t}{ }^{2}}\right)
$$

Information:

$r_{x y}=$ Test reliability coefficient

$\mathrm{n} \quad=$ Number of items excluded in the test

$\sum S_{i}{ }^{2}=$ The sum of the score variance per item

$S_{t}{ }^{2}=$ Variance of total score

c. Discernment

Calculating the distinguishing power using the following formula:

Information:

$$
D P=\frac{\bar{X}_{A}-\bar{X}_{B}}{S M I}
$$

$D P \quad=$ Distinguishing power

$\bar{X}_{A} \quad=$ The average score of students in the upper group

$\bar{X}_{B} \quad=$ The average score of students in the lower group

SMI = maximum ideal score

d. Level of Difficulty

Calculating the difficulty level of each item, the following formula is used:

Information:

$$
I K=\frac{\bar{X}}{S M I}
$$

IK = difficulty index

$\bar{X}=$ The average score of the answers to each question

$\mathrm{SMI}=$ maximum ideal score

\subsection{Results of instrument analysis}

The checklist sheet of the media feasibility instrument in the form of expert validity is given a judgment by an expert lecturer to find out that each indicator is fulfilled for the assessment of the feasibility of teaching materials according to BSNP for PAKARNA media. The assessment of the feasibility of the PAKARNA media has 3 indicators, namely components of the feasibility of content, presentation and graphics.

The assessment has been carried out on the expert validation checklist sheet to find out whether learning using PAKARNA media meets teaching materials.

\subsection{Data collection techniques}

The data used in the study of course must be collected first, the data collection techniques in this study can be seen in Table Data collection techniques 
Table 2. Table Data collection techniques

\begin{tabular}{|c|c|c|c|c|}
\hline No & $\begin{array}{c}\text { Data } \\
\text { Sources }\end{array}$ & Aspect & $\begin{array}{c}\text { Data Collection } \\
\text { Techniques }\end{array}$ & Research Instruments \\
\hline 1 & $\begin{array}{c}\text { Feasibility } \\
\text { Expert }\end{array}$ & $\begin{array}{c}\text { Team for } \\
\text { learning media }\end{array}$ & Assessment sheet & Rubric checklist \\
\hline 2 & Student & $\begin{array}{c}\text { Students' } \\
\text { mathematical } \\
\text { communication } \\
\text { skills }\end{array}$ & Pretest and posttest & Question sheet \\
\hline 3 & Student & $\begin{array}{c}\text { Assessment of } \\
\text { attitudes towards } \\
\text { learning, media } \\
\text { and } \\
\text { mathematical } \\
\text { communication } \\
\text { tests }\end{array}$ & Questionnaire & Attitude scale \\
& \begin{tabular}{c} 
quannaire \\
\hline
\end{tabular}
\end{tabular}

\subsection{Data analysis technique}

The data that has been collected is then analyzed by manual calculation. The data analysis techniques for each problem formulation are as follows.

1. The formulation of the first problems regarding the process of developing learning media was carried out with the modified Research and Development (R\&D) method of Sugiyono, namely: Potential and Problems, data collection, product design, design validation, design revision, product testing, final products. Then analyzed with the rating scale measurement scale.

2. Whether the PAKARNA media is suitable for use is carried out by means of media feasibility validation analysis by experts and teachers. The data used is in the form of a media feasibility assessment sheet which consists of the feasibility components of the technician, presentation and graphic of the PAKARNA which is carried out by mathematics experts and teachers. Where in the assessment sheet there are various predetermined criteria then these criteria are assessed whether they fulfill the purpose of the items as described in the item predictions. The research data were then analyzed using the rating scale measurement scale determined by the following formula:

Information:

$$
\mathrm{p}=\frac{\text { score from data collection }}{\text { Ideal score }} .100 \%
$$

$\mathrm{P} \quad=$ percentage of product validity

Ideal score $\quad=$ highest score per number of respondent $\mathrm{x}$ number of items

3. Differences in the achievement of mathematical communication skills between students who use PAKARNA learning media and students who use expository learning. The answer to the formulation of the problem can be found by testing the difference between the means of the posttest results between the experimental class and the control class. Then if the results of the two averages are normally distributed, then proceed with the " $\mathrm{t}$ " test. However, if the results of the two-mean difference test 
on the posttest results are not normally distributed, the homogeneity is not tested, but non-parametric statistics are used, namely by testing the Mann-Whitney. To perform the " $\mathrm{t}$ " test, the assumptions that must be fulfilled are that the data is normally distributed and homogeneous. If all assumptions have been fulfilled, then proceed with the "t" test.

4. Students' attitudes towards learning mathematics using PAKARNA media, so the data is analyzed quantitatively, that is, by looking at the average acquisition of attitude scores and the percentage of positive and negative attitudes. Furthermore, the average score of the students was compared with a neutral score. $h$ The neutral score in this study is 2,50. The attitude scale categorization is:

$\bar{x}>2,50$ : Positive

$\bar{x}=2,50:$ Neutral

$\bar{x}<2,50$ : Negative

Information :

$\bar{x}=$ Average student score item

In addition to analyzing the average student scores, he also analyzed the percentage of positive attitudes and negative attitudes of each report. For positive statements, positive attitude is approval attitude (number of S and SS responses) and negative attitude is attitude of disapproval (number of TS and SSS responses). For negative statements, a positive attitude is an attitude of disapproval (the number of TS and STS responses) and a negative attitude is an attitude of approval (the number of responses from S and SS). To see the percentage of subjects who have positive responses to applied learning, it is calculated based on the Kuntjaraningrat criteria as follows:

$$
\text { Percentage of Answers }=\frac{\text { frequency of answers }}{\text { many respondents }} \times 100 \%
$$

\section{Results and Discussion}

The research was conducted from 22 July 2020 to 31 August 2020. The research was conducted in 6 meetings. The first meeting for the pretest, four meetings for the learning, and the last fall meeting for the posttest. The material taught in this research is arithmetic sequences and series. The learning that is carried out is carried out online using the zoom meeting application for the control class due to the rules for learning at home and home visits for the experimental class.

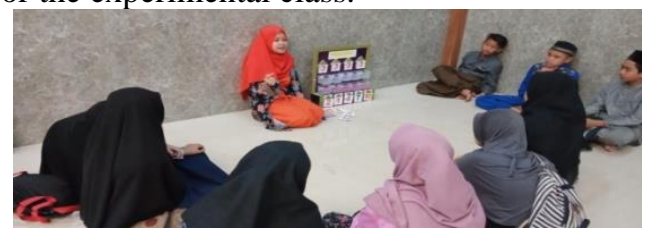

Fig. 1. Architecture Experiment Class

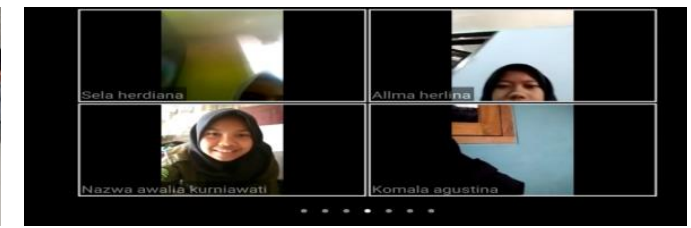

Fig. 2. Control Class

a. PAKARNA media development description

PAKARNA learning media (Color Number Board) is a learning medium designed to make it easier for students to understand the concept of arithmetic sequence and series material. PAKARNA is made using a board designed in which there are several container boxes which can then be filled with marbles with the number of marbles according to the number of terms 
in the arithmetic sequence and sequence, where the marbles represent numbers. The container box in PAKARNA contains two groups of boxes marked using a plain image for negative arithmetic sequences and series and a flower-illustrated box used for positive arithmetic sequences and series.

In PAKARNA there are also tree pictures that can be used to show the number of marbles in the container box or show the number of terms. There is a house-shaped board that can be filled in with numbers indicating the difference in the number of marbles in the box or to show the difference between the tribes. And there are numbers to symbolize or show numbers on the house shape boards and tree images that are different values and tribes.

b. Description of the expert validity checklist sheet data

The feasibility of PAKARNA media is based on the rules of eligibility of teaching materials according to BSPN. There are 3 aspects assessed by media experts, namely the content feasibility component which has 11 items, the presentation component which has 2 items and the graphic component which has 3 items. The total items on the media expert validity checklist were 16 items. All these aspects were assessed by media experts from the Department of Mathematics Education, UIN Bandung and class VIII mathematics teachers of SMP Muhammadiyah 10 Bandung.

Table 3. Feasibility Assessment of Expert Media by Experts

\begin{tabular}{|c|l|c|c|c|}
\hline \multirow{2}{*}{$\begin{array}{c}\text { N } \\
\text { o }\end{array}$} & \multicolumn{1}{|c|}{ Validator } & \multicolumn{3}{|c|}{ Aspect (\%) } \\
\cline { 3 - 5 } & \multicolumn{1}{|c|}{$\begin{array}{c}\text { Feasibili } \\
\text { ty of } \\
\text { Content }\end{array}$} & $\begin{array}{c}\text { Serving } \\
\text { Compone } \\
\text { nts }\end{array}$ & $\begin{array}{c}\text { Graphic } \\
\text { Compo } \\
\text { nents }\end{array}$ \\
\hline 1 & $\begin{array}{l}\text { Media Expert } \\
\text { (Prof. Dr. Hj. Rahayu Kariadinata, M.Pd.) }\end{array}$ & $91 \%$ & $88 \%$ & $92 \%$ \\
\hline 2 & $\begin{array}{l}\text { Media Expert } \\
\text { (Dra. Juariah, M.Pd.) }\end{array}$ & $89 \%$ & $88 \%$ & $92 \%$ \\
\hline 3 & $\begin{array}{l}\text { Media Expert } \\
\text { (Hamdan Sugilar, M.Pd.) }\end{array}$ & $80 \%$ & $63 \%$ & $83 \%$ \\
\hline 4 & $\begin{array}{l}\text { Mathematics Teacher } \\
\text { (Siti Rohmah Sakinah, S.Pd.) }\end{array}$ & $61 \%$ & $75 \%$ & $67 \%$ \\
\hline
\end{tabular}

According to media expert Prof. Dr. Hj. Rahayu Kariadinata, M.Pd. based on the feasibility of the content obtained $91 \%, 88 \%$ presentation component and $92 \%$ graphic component. And get an overall score of 58 or if the percentage is $91 \%$ which if interpreted means that the PAKARNA media is very feasible to be used as learning media.

Media feasibility according to media expert Dra. Juariah, M.Pd. based on the feasibility of the content obtained $89 \%, 88 \%$ presentation component and $92 \%$ graphic component. And get an overall score of 57 or if the percentage is $89 \%$ which if interpreted means that the PAKARNA media is very feasible to be used as learning media.

Media feasibility according to media expert Hamdan Sugilar, M.Pd. based on the feasibility of the content obtained $80 \%, 63 \%$ presentation component and $83 \%$ graphic component. And get an overall score of 50 or if the percentage is $78 \%$ which if interpreted means that the PAKARNA media is suitable to be used as learning media but must be revised first. 
Media feasibility according to media expert Siti Rohmah Sakinah, S.Pd. based on the feasibility of the content obtained $61 \%, 75 \%$ serving components and $67 \%$ graphic components. And get an overall score of 41 or if the percentage is $64 \%$ which if interpreted means that the PAKARNA media is suitable to be used as learning media but must be revised first.

c. Description of pretest data

The comparison of the increase in students' mathematical communication skills can be seen from the results of the pretest and posttest. For more details regarding the control class pretest and experimental class pretest data.

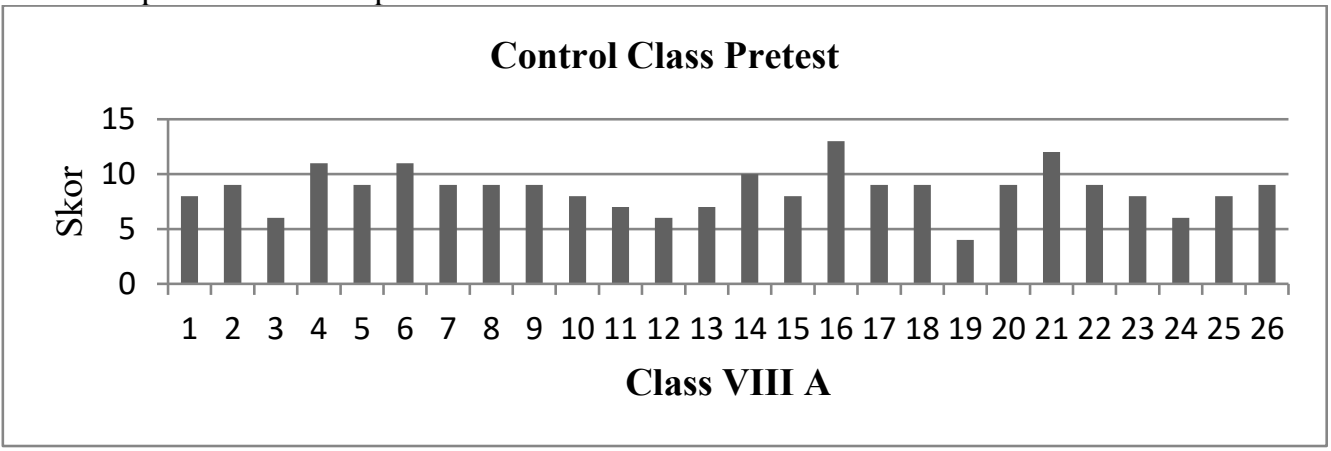

Fig. 3. Control Class Pretest

Based on Figure 3, it can be seen that the lowest score of the control class or class VIII A is 4,00 and the highest score is 13,00 . It can be seen that the lowest score of the experimental class or class VIII B is 4,00 and the highest score is 12,00 .

d. Posttest data description

The posttest was given to find out whether there was a difference after the students were treated with PAKARNA media.

\section{Eksperiment Class Pretest}

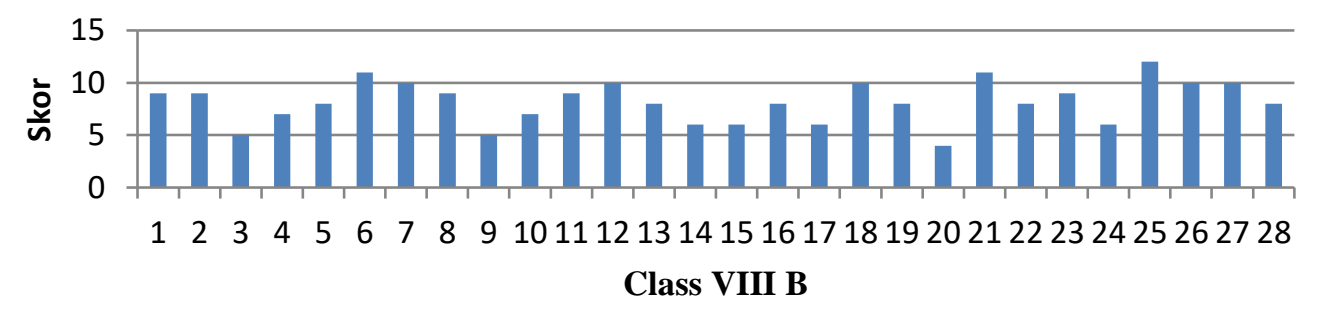

Fig. 4. Experiment Class Pretest 


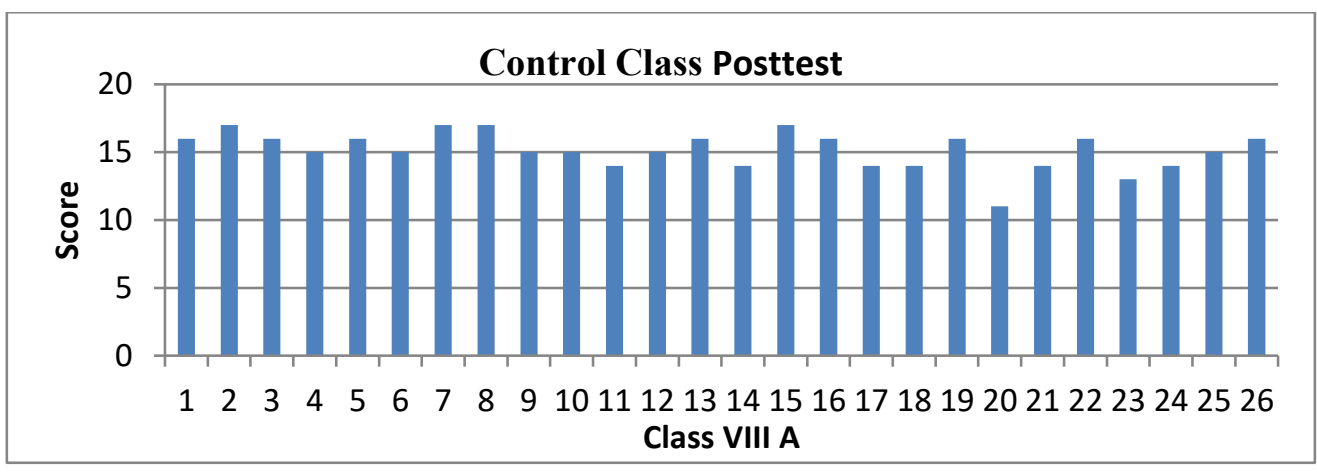

Fig. 5. Control Class Posttest

Based on Figure, it can be seen that the lowest score of the control class or class VIII A is 11,00 and the highest score is 17,00 .

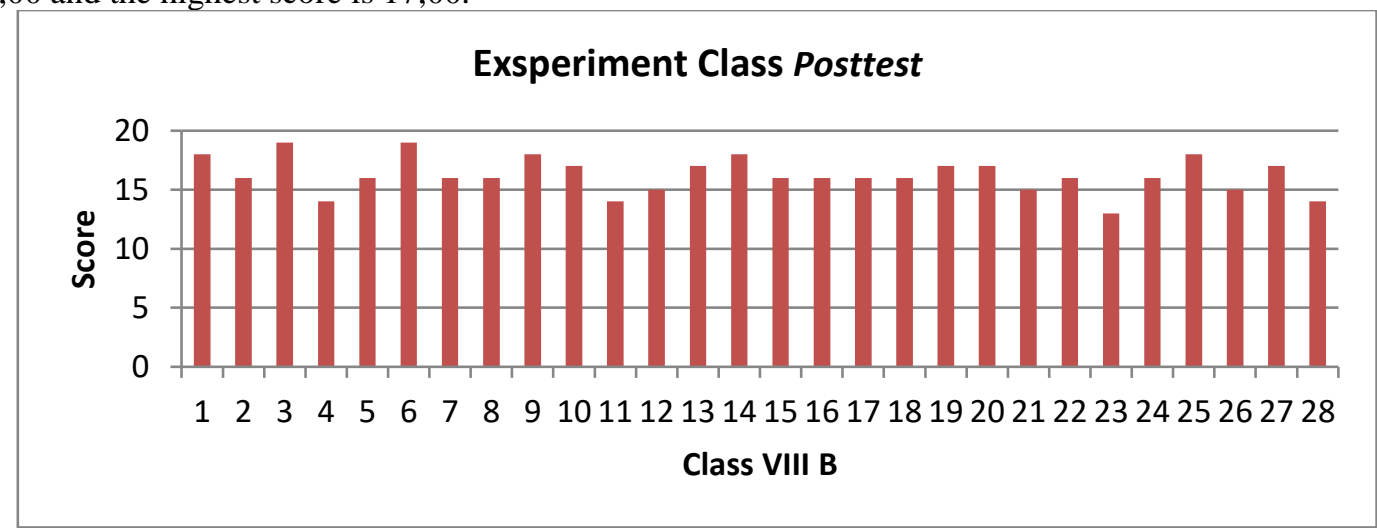

Fig. 6. Experiment Class Posttest

It can be seen that the lowest score of the experimental class or class VIII B is 13.00 , the highest score is 19.00 . The descriptive statistical results of pretest, posttest and N-Gain data.

Table 4. The descriptive statistical results of pretest, posttest and N-Gain data

\begin{tabular}{|c|l|c|c|c|c|c|}
\hline \multicolumn{2}{|c|}{ Score } & Average & $\begin{array}{c}\text { Standard } \\
\text { Deviation }\end{array}$ & Maximum & Minimum & $\begin{array}{c}\text { Ideal } \\
\text { Score }\end{array}$ \\
\hline \multirow{2}{*}{ Pretest } & Experiment & 8,18 & 2,02 & 12,00 & 4,00 & \\
\cline { 2 - 6 } & Control & 8,58 & 1,94 & 13,00 & 4,00 & \multirow{2}{*}{20,00} \\
\hline \multirow{2}{*}{ Posttest } & Experiment & 16,25 & 1,51 & 19,00 & 13,00 & \\
\cline { 2 - 6 } & Control & 15,15 & 1,41 & 17,00 & 11,00 & \\
\hline \multirow{2}{*}{ N-Gain } & Experiment & 0,40 & - & - & - & - \\
\cline { 2 - 7 } & Control & 0,33 & - & - & - & - \\
\hline \multirow{2}{*}{$\begin{array}{c}\text { N-Gain } \\
\text { Interpretation }\end{array}$} & Experiment & Medium & - & - & - & - \\
\cline { 2 - 7 } & Control & Medium & - & - & - & - \\
\hline
\end{tabular}


e. Description of the n-gain data (pretest and posttest)

It can be seen that the highest N-gain obtained by the control class or class VIII A students is 0,60 . Where as for the highest $\mathrm{N}$-gain of the experimental class, the highest $\mathrm{N}$-gain value is 0,70 . The average $\mathrm{N}$-gain value of the control class is 0,33 , which is lower than the $\mathrm{N}$-gain in the experimental class, which is 0,40 .

f. Attitude scale data description

The attitude scale is given after giving treatment to the experimental group or class that gets learning with PAKARNA media for learning mathematics. It can be seen that the average student attitude towards learning mathematics is 2,96, the average student attitude towards learning mathematics using PAKARNA learning media is 2,75 and the average student attitude towards mathematical communication problems is 2,78 . The three average values are greater than the neutral score of 2,50. PAKARNA media development in accordance with the stages of Research and Development (R\&D), research and development or Research and Development $(R \& D)$ is a process or steps to develop a new product, or perfect an existing product, which can be held accountable. The product in question is not only in the form of objects such as books and modules, but can also be soft devices such as computer programs for data processing or classroom learning.

There are 3 aspects assessed by media experts, namely the content feasibility components, presentation components and graphic components of PAKARNA. The total items on the media expert validity checklist were 16 items. All these aspects were assessed by media experts, namely 3 lecturers in the Department of Mathematics Education, UIN Bandung and a class VIII mathematics teacher at SMP Muhammadiyah 10 Bandung.

The percentage of each aspect of the content aspect, presentation component and graphics can be seen in Table

Table 5. Percentage of Media Eligibility

\begin{tabular}{|c|c|c|}
\hline Aspek Penilaian & Persentase (\%) & Interpretation \\
\hline Eligibility Content & 80 & Proper \\
\hline Serving Components & 78 & Proper \\
\hline Graphic Components & 83 & Very Proper \\
\hline
\end{tabular}

As for the percentage of media validation for the feasibility of the media as a whole is $80 \%$, meaning that the PAKARNA media can be used as a learning medium with a feasible category. Based on the results of the calculation on the slip control, it is found that $\mid \mathrm{F}_{\mathrm{T}}-$ $\mathrm{F}_{\mathrm{S}}$ llargest $<$ value of the Komogorov-Smirnov table $=0,12<0,26$ so that $\mathrm{H}_{0}$ is accepted, meaning that the data is normally distributed. Based on the calculation results in the experimental class, it is found that $\left|\mathrm{F}_{\mathrm{T}}-\mathrm{F}_{\mathrm{S}}\right|$ the largest $<$ Komogorov-Smirnov table value $=$ $0,17<0,25$ so that $\mathrm{H}_{0}$ is accepted, meaning that the data is normally distributed. Furthermore, a test was carried out to determine the variance of the two data in the control class and experimental class, it was obtained that $F_{\text {count }}<F=1,15<1,94$ then $\mathrm{H}_{0}$ was accepted, that is, the two variances tested were homogeneous.

The " $t$ " test for the $\mathrm{N}$-gain score was calculated by the " $t$ " test using Microsoft Excel. As for the formulation of the statistical hypothesis of the " $t$ " test, the N-gain score is as follows: 
$\mathrm{H}_{\mathrm{o}}: \mu_{1}=\mu_{2}$ : There is no difference in the achievement of mathematical communication skills between students who use PAKARNA (Papan Angka Berwarna) learning media and students using expository learning.

$\mathrm{H}_{\mathrm{a}}: \mu_{1} \neq \mu_{2}$ : There are differences in the achievement of mathematical communication skills between students who use PAKARNA (Papan Angka Berwarna) learning media and students who use expository learning.

Based on the results of calculations using a significant level of 0,05 , it is found that $t$ count $(2,17) \geq \mathrm{t}$ table $(2,01)$, so $\mathrm{H}_{0}$ is rejected and $\mathrm{Ha}$ is accepted. So that there are differences in the achievement of mathematical communication skills between students who use PAKARNA learning media (Papan Angka Berwarna) and students who use expository learning.

Student responses to mathematics learning towards PAKARNA learning media are carried out a priori way. The attitude scale given is an attitude scale that has been consulted with the supervisor, namely an attitude scale which contains 25 questions. The student's attitude towards learning mathematics has a value of 2,96 while a neutral score is 2,50 . So, students have a positive response to learning mathematics and seriously participate in the mathematics learning process. $\mathrm{h}$ The student's attitude towards learning mathematics using PAKARNA learning media shows a score of 2,75, greater than a neutral score of 2,50. Students give positive responses to mathematics learning using PAKARNA learning media. Mean while, for students' attitudes towards mathematical communication questions, students also gave positive responses. It can be seen with the acquisition of a score of 2,78 , which is greater than a neutral attitude, which is 2,50 .

\section{Conclusion}

Based on the results of research conducted at SMP Muhammadiyah 10 Bandung with a population of all VIII students in the 2020/2021 academic year, by implementing learning using PAKARNA media to improve students' mathematical communication skills in arithmetic sequence material, in general, several things were drawn which became the following conclusions. The process of developing PAKARNA learning media in each stage runs according to Sugiyono's modified Research and Development (R \& D) stages which have been modified in 7 steps. These 7 stages are potential problems and problems, at this stage the researcher makes observations, interviews and conducts tests to find out students 'initial abilities, the result is that students' mathematical communication skills are still lacking. The second is the collection of data related to the results of observation data, the results of interviews with teachers and students, and the results of students' mathematics communication skills and reviewing literature such as journals, mathematics books of SMP/MTs class VIII; Product design, namely designing PAKARNA media from various tools and materials that have been prepared; Design validation, media display, program and learning were then assessed by experts and mathematics teachers at SMP Muhammadiyah 10 Bandung, and the result was that there were things that had to be revised, namely in the way PAKARNA media worked.

Design revision, a design revision was carried out by adding a plastic container box which is used to distinguish negative arithmetic sequences; Product testing, this trial uses class VIII $\mathrm{B}$ and students are enthusiastic in using the PAKARNA media; Final products, PAKARNA media revised results that have been validated by experts and teachers, tested the feasibility of the product, and then can be used in mathematics learning with materials in line and arithmetic 
series. There are three aspects assessed by media experts, namely the content feasibility components, presentation components and graphic components from PAKARNA assessed by media experts and mathematics teachers. From this assessment, it was obtained that the percentage of media validation for the overall feasibility was $80 \%$, that the PAKARNA media was feasible to be used as a classroom learning medium. There are differences in the achievement of mathematical communication abilities between students using PAKARNA learning media and students using expository learning. This can be seen from the differences in class achievement using PAKARNA media and expository classes. Most (69\%) students have a positive attitude towards learning mathematics using PAKARNA learning media. This means that students are happy with learning using PAKARNA media.

\section{References}

[1] Sukmadinata, Nana Syaodih. (2011). Metode Penelitian Pendidikan (Bandung: Rosdakarya).

[2] Sugiyono. (2013). Metode Penelitian Kuantitatif, Kualitatif dan R \& D, (Bandung: Alphabeta).

[3] Pustilitjaknov. Tim. (2008). Metode Penelitian Pengembangan (Pusat Penelitian Kebijakan dan Inovasi Pendidikan, Badan Penelitian dan Pengembangan Departemen Pendidikan Nasional).

[4] Nu'man, Mulin. (2019). Pengembangan Bahan Ajar Statistika Penelitian Pendidikan Matematika. Jurnal Mercumatika : Jurnal Penelitian Matematika dan Pendidikan Matematika. Vol. 3, No. 2, April 2019, pp. 114-128, ISSN: 2548-1819.

[5] Komalasari, Kokom. (2010). Pembelajaran Kontekstual dan Aplikasi. Bandung: Refika Aditama.

[6] Anwar, M. (2010). Pengembangan Media Pembelajaran Berbasis Teknologi Informasi. Jurnal Pendidikan Akuntansi Indonesia, Vol. 8 No. 2 Hal. 1-10.

[7] Lasmiyati, \& Harta, I. (2014). Pengembangan Modul Pembelajaran untuk Meningkatkan Pemahaman Konsep dan Minat Siswa SMP. Pythagoras: Jurnal Pendidikan Matematika., Vol. 9 No.2, Hal. 161-174.

[8] Susilana, Rudi. dan Riyana, Cepi. (2009). Media Pembelajaran: Hakikat, Pengembangan, Pemanfaatan, dan Penilaian. Bandung: CV Wacana Prima. http://www.pengertianahli.com\#/2014/07/pengertian-media-dan-jenis media.html (diakses 30 Februari 2021).

[9] Azhar, Arsyad. (2011). Media Pembelajaran (Jakarta: PT Raja Grafindo Persada).

[10] Rusman. (2017). Belajar dan Pembelajaran berorientasi Standar Proses Pendidikan. Jakarta: Kencana.

[11] Sadiman, Raharjo, dan dkk. (2006). Media Pendidikan. Jakarta: Rajawali Press.

[12] Lyman, Ott., and Longnecker, Michael. (2010). An Introduction to statistics with data analysis. Belmont: Brooks/Cole, Cengage Learning. 